RECEIVED:

17 April 2020

ACCEPTED:

20 May 2020

RELEASED:

20 July 2020
UDC 331.103

DOI 10.26661/2522-1566/2020-2/12-03

\title{
THE EFFECT OF EXPERTISE ON EMPLOYEE PERFORMANCE WITH WORK MOTIVATION AS INTERVENING VARIABLE
}

\section{Syawaluddin}

STIE Professional Manajemen

College Indonesia

Medan, Indonesia

ORCID ID: 0000-0001-6295-0632
Erwin

STIE Mikroskil

Medan, Indonesia

ORCID ID: 0000-0003-4507-5033

\author{
Joni \\ STMIK TIME \\ Medan, Indonesia \\ ORCID ID: 0000-0002-6270-6522
}

*Corresponding author email: syawaluddinpmci@gmail.com

\begin{abstract}
This study is aimed at analyzing the effect of expertise on employee performance in PT Dinamika Abadi Medan with work motivation as an intervening variable. This research involved 124 company employees. Data analysis tools used in hypothesis testing were validity, reliability and path analysis. The research results showed that expertise had a significant effect on employee performance in PT Dinamika Abadi Medan. It means that the higher the expertise provided, the higher the employee performance in PT Dinamika Abadi Medan. Expertise significantly impacted the work motivation of employees in PT Dinamika Abadi Medan. It means that the higher the expertise provided, the higher the work motivation of employees in PT Dinamika Abadi Medan. Work motivation had a significant effect on employee performance in PT Dinamika Abadi Medan. This case means that the higher the employee work motivation, the higher the employee performance in PT Dinamika Abadi Medan. The empirical test resulted in Z count (36.0) $>\mathrm{Z}$ table (1.96) so that work motivation could mediate the relationship between expertise and employee performance. Therefore, $\mathrm{H} 4$ was accepted. This case means that the higher the expertise provided, the higher the employee work motivation so that employee performance increased as well.
\end{abstract}

Keywords: expertise, work motivation, employee performance, company bussiness, human resources.

JEL Classification: O15, M51, M54.

\section{INTRODUCTION}

The entrepreneurship world is now required to create high employee performance for developing companies. Companies must be able to build and improve performance in their environment. Several factors influence the success of the company. One significant factor is human resources because human resources are actors of all levels, from planning to evaluation; they can take advantage of other resources owned by the organization or company (Dito, 2010). The human resources of a company play an essential role. The workforce has excellent potential to carry out company activities. The potential of every human resource in the company must be utilized as well as possible to provide optimal output. 
Syawaluddin, Erwin and Joni (2020), "The effect of expertise on employee performance with work motivation as intervening variable”, Management and entrepreneurship: trends of development, Vol. 2, Issue 12, pp. 36-47, available at: https://doi.org/10.26661/2522-1566/2020-2/12-03

The achievement of company goals does not only depend on modern equipment, complete facilities, and infrastructure but rather depends more on the people carrying out the work. Employee performance strongly influences the success of an organization. Every organization and company will always try to improve employee performance to achieve the company goals. Therefore, the company must improve its performance so that all agreed goals can be achieved.

The success or failure of the company to achieve the agreed goals or targets significantly requires employees who support all the vision and mission of the company. Efendi (2002) argued that performance is the result of work produced by employees or actual behavior performed according to their roles in the organization or company. The formation of excellent employee performance is expected to compete with other companies so that the company can be recognized as a quality company (Damayanti et al., 2013). The progress of a company can be seen from the comparison of targets set by the company with the realization of the performance achieved.

Apart from employee performance, work expertise is one of the main elements in employment because a person can complete the work according to the duties and responsibilities of the organization. Hence, organizational goals can be achieved effectively and efficiently (Simamora, 2004, p. 337). The effectiveness of management within an organization will succeed if the organization can recognize individual differences. Gibson stated that to understand individual differences, leaders must be able to: 1). Observe and recognize differences; 2). Study the behaviors affecting the individual; 3). Finding the relationship between these variables. Many people understand each employee must own a valuable asset, namely, expertise. Basically, the employee expertise will be beneficial in completing tasks and work provided by the company. However, some people could not understand this case well. They work with not optimal expertise so that automatically, they have reduced their performance in doing the tasks and work given. Along with that, Efendi (2002) argued that motivation is the factor that directs and encourages someone's behavior or desire to carry out an activity expressed in the form of hard or weak work. Understanding of employee motivation will be very crucial concerning achieving goals, namely, maximum organizational performance. Therefore, one of the best ways to increase employee performance capacity is by connecting expertise to work motivation.

Companies really need to maintain and motivate employees to improve their performance further to enhance the company's performance. In the end, the company is not only superior in competition but also able to maintain its survival, even increase profitability and develop its business (Nugroho, 2009). Hasibuan (2002) said that one of the goals of providing expertise is motivation. If the services provided are large enough, the manager will easily motivate his subordinates. According to Robbins (2007), motivation is a process that plays a role in the intensity, direction, and duration of individual efforts towards achieving goals. If an employee considers that the expertise provided by the company is in accordance with employees' expectations, then they will be motivated to improve their performance. The results of interviews with several employees revealed that the performance of PT Dinamika Abadi's employees decreased significantly due to the decline in the expertise of PT Dinamika Abadi's employees. Each employee's expertise was not in line with company expectations. Based on research gaps and phenomena that occur in PT Dinamika Abadi, this study was conducted by re-testing and conducting a scientific study entitled Effect of Expertise on Employee Performance with Work Motivation as Intervening Variables in PT Dinamika Abadi Medan.

\section{LITERATURE REVIEW}

\section{Employee Performance}

Employee performance is the work of quality and quantity achieved by an employee in carrying out their duties based on the responsibilities given to him (Mangkunegara, 2009). The level of success performance includes quantitative and qualitative aspects. Meanwhile, according to 
(Siswanto in Sandy, 2015, p. 11), performance is an achievement of someone in carrying out the tasks and jobs given to him. Understanding of performance, according to Moeheriono (2012, p. 95), namely performance, or performance is a picture of the achievement level of the implementation of activities or policies in realizing the goals, objectives, vision, and mission of the organization as outlined through the strategic planning of an organization. Employee performance indicator, according to Edison, et al. (2017, p. 193) is to achieve or assess performance; some dimensions serve as benchmarks, namely targets, quality, time of completion, compliance with principles.

\section{Expertise}

Expertise is an interest or talent that must be possessed by someone. Expertise enables people to carry out and complete tasks correctly with maximum results. People's expertise can be obtained from formal or non-formal education, which later must be continuously improved. One source of increased expertise can come from experiences in a particular field (Wardani, 2010). Robbins (2006, p. 46) defined that expertise is the capacity of individuals to carry out various tasks in certain jobs. An Individual's abilities are basically composed of two sets of factors, namely intellectual and physical abilities. Hasibuan (2003) revealed that expertise includes three indicators, namely: 1. Technical skills include the ability to apply specific knowledge or expertise. All jobs require a number of specific skills, and many individuals develop their technical expertise at work. 2. Human skills (ability) consisting of the ability to work together, understand, and motivate others, both individually and in groups. 3. Conceptual skills are mental ability to analyze and diagnose complicated situations.

\section{Work Motivation}

Pamela and Oloko (2015) stated that motivation is the key to a successful organization in maintaining the continuity of work in the organization with a strong way and assistance to survive. Chukwuma and Obiefuna (2014) addressed that motivation is the process of arousing behavior, maintaining behavioral progress, and channeling specific behavioral actions. Thus, motives (needs and desires) encourage employees to act. Steers and Porter (in Miftahun and Sugiyanto 2010) stated that work motivation is an effort that can create behavior, direct behavior, and maintain behavior appropriate to the work environment in the organization. Work motivation is a basic human need derived from expertise, expected to meet the desired basic needs. Those needs impact on the success of an activity. Employees with high work motivation will try to get their work done as well as possible. Indicators of work motivation, according to Maslow in Sofyandi and Garniwa (2007, p. 102), are namely physiological, security, needs, appreciation, and self-actualization needs.

\section{PAPER OBJECTIVE}

This study is aimed at analyzing the effect of expertise on employee performance in PT Dinamika Abadi Medan with work motivation as an intervening variable. 
Syawaluddin, Erwin and Joni (2020), "The effect of expertise on employee performance with work motivation as intervening variable", Management and entrepreneurship: trends of development, Vol. 2, Issue 12, pp. 36-47, available at: https://doi.org/10.26661/2522-1566/2020-2/12-03

\section{Framework}

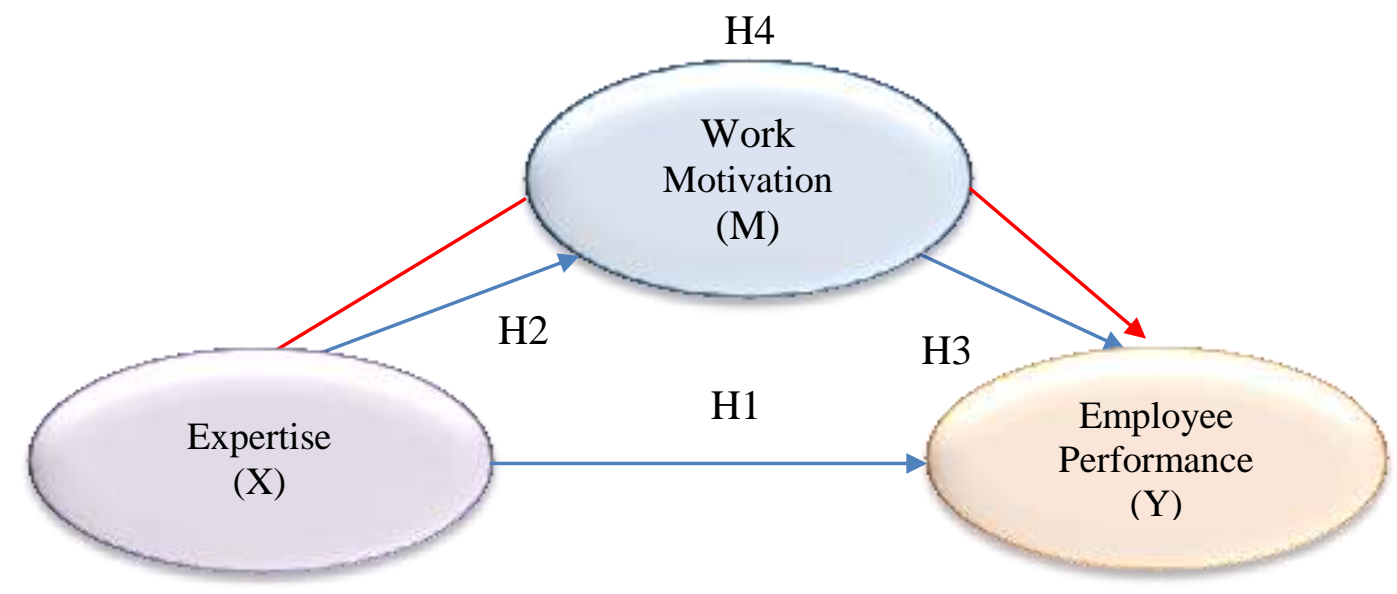

Notes:

$=$ Direct relationship between variables

$=$ Indirect relationship (mediation)

Figure 1. The Effect of Expertise on Employee Performance in PT Dinamika Abadi Medan with Work Motivation as Intervening Variable

Source: Own compilation

\section{METHODOLOGY}

Population

Populations in the research were 124 employees of PT Dinamika Abadi.

\section{Sample}

There were 124 employees in this study counted since the observation until questionnaire distribution.

Data Collection Methods

Data collection methods are observation. interview. literary study. questionnaire. This study used a Likert scale consisting of strongly disagree. disagree. quite disagree. agree. strongly agree. Every answer was given value with the following scales: Strongly agree $=5$. Agree $=4$. Quite agree $=$ 3. Disagree $=2$. Strongly disagree $=1$ (Sugiyono, 2009, p. 172) .

Data Analysis Technique

Descriptive Statistical Analysis

The descriptive statistical analysis focuses on collecting, processing, presenting, and analyzing data (Wahyuni, 2011, p. 12).

Statistical T-Test

Criteria of test with a significance level of 0.05 were determined as follow:

If the significance $t>0.05$, the hypothesis is refused (regression coefficient is not significant) If the significance $t<0.05$, the hypothesis is accepted (regression coefficient is significant). 
Path Analysis

This research employed path analysis. The following is the similarity:

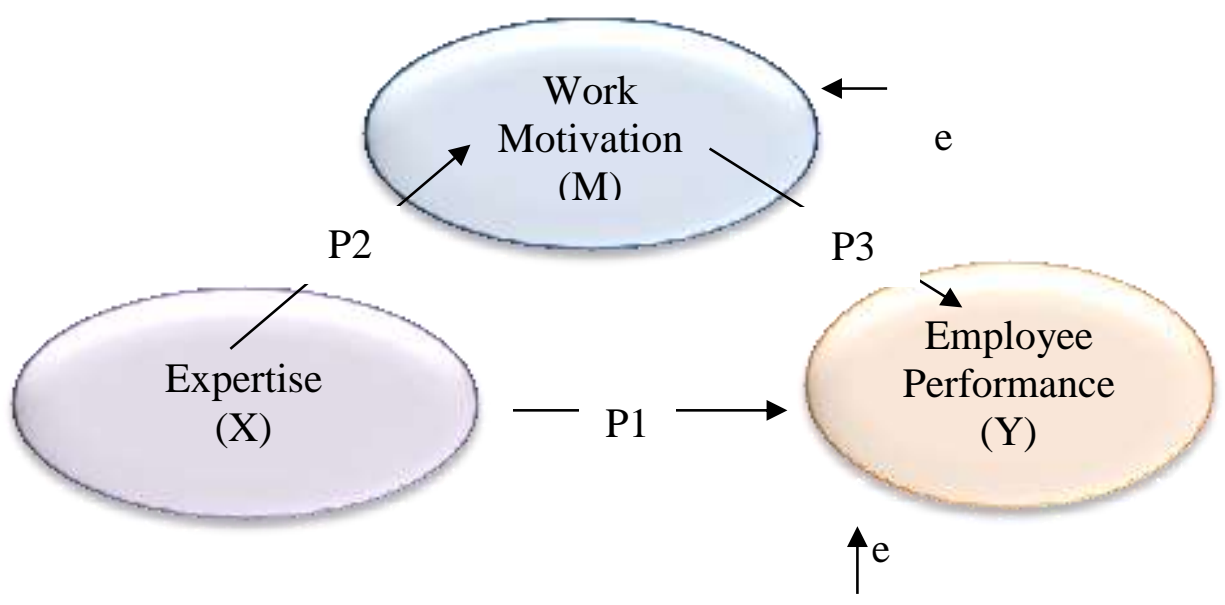

Figure 2. Model Analisis Jalur (Path Analysis)

Source: Own compilation

The structural equation is the multiple of the regression test as follow:

$\mathrm{M}=\beta_{1} \mathrm{X}+\mathrm{e} \ldots \ldots \ldots \ldots . . .($ Model 1$)$

$\mathrm{Y}=\beta_{1} \mathrm{X}+\beta_{2} \mathrm{M}+\mathrm{e} \ldots . . .($ Model 2$)$

Notes:

Y : $\quad$ Dependent variable. namely employee performance in PT Dinamika Abadi

M : $\quad$ Mediation variable. namely motivation in PT Dinamika Abadi.

$\mathrm{X}$ : $\quad$ Independent variable. namely Expertise

$\beta_{1.2}: \quad$ Regression coefficient

e: Error

Path Analysis

The regression analysis was done using SPSS 22.0 with the following results to predict parameter. Substructure 1: $\quad M=\beta_{1} X+e$

The results of data analysis calculation are as follow:

Coefficients of Substructure 1 (Model 1)

Table1

Coefficients $^{\mathrm{a}}$

\begin{tabular}{|c|c|c|c|c|c|c|}
\hline & \multirow{2}{*}{ Model } & \multicolumn{2}{|c|}{ Unstandardized Coefficients } & $\begin{array}{l}\text { Standardized } \\
\text { Coefficients }\end{array}$ & \multirow[b]{2}{*}{$\mathrm{T}$} & \multirow[b]{2}{*}{ Sig. } \\
\hline & & B & Std. Error & Beta & & \\
\hline \multirow[t]{2}{*}{1} & (Constant) & 23.363 & 2.060 & & 11.342 & .000 \\
\hline & $X$ & .625 & .064 & .338 & 3.972 & .000 \\
\hline
\end{tabular}

a. Dependent Variable: $M$

Substructure $2: Y=\beta_{1} X+\beta_{2} M+e$

The results of data analysis calculation are as follow. 
Syawaluddin, Erwin and Joni (2020), "The effect of expertise on employee performance with work motivation as intervening variable", Management and entrepreneurship: trends of development, Vol. 2, Issue 12, pp. 36-47, available at: https://doi.org/10.26661/2522-1566/2020-2/12-03

Table 2

Coefficients of Substructure 2 (Model 2)

Coefficients $^{\mathrm{a}}$

\begin{tabular}{|c|c|c|c|c|c|c|}
\hline & \multirow{2}{*}{ Model } & \multicolumn{2}{|c|}{ Unstandardized Coefficients } & Standardized & \multirow{2}{*}{$\mathrm{T}$} & \multirow{2}{*}{ Sig. } \\
\hline & & B & Std. Error & Beta & & \\
\hline \multirow[t]{3}{*}{1} & (Constant) & 15.017 & 3.356 & & 4.475 & .000 \\
\hline & $X$ & .638 & .078 & .220 & 2.420 & .017 \\
\hline & $\mathrm{M}$ & .719 & .103 & .193 & 2.125 & .036 \\
\hline
\end{tabular}

a. Dependent Variable: Y

Based on calculations on substructures 1 and 2, the direct and indirect effects, as well as the total effect between variables, could be identified. The following is the calculation of the effect between variables.

Table 3

Direct Effect, Indirect Effect and Total Effect of Expertise. Work Motivation and Employee Performance

\begin{tabular}{|l|l|c|c|c|}
\hline \multicolumn{2}{|c|}{ Variable } & $\begin{array}{c}\text { Direct } \\
\text { Effect }\end{array}$ & $\begin{array}{c}\text { Indirect Effect } \\
\text { through Work } \\
\text { Motivation }\end{array}$ & $\begin{array}{c}\text { Total } \\
\text { Effect }\end{array}$ \\
\hline Expertise & $\begin{array}{l}\text { Employee } \\
\text { Performance }\end{array}$ & 0.188 & 0.056 & 0.244 \\
\hline Expertise & Work Motivation & 0.255 & - & 0.255 \\
\hline Work Motivation & $\begin{array}{l}\text { Employee } \\
\text { Performance }\end{array}$ & 0.219 & - & 0.219 \\
\hline
\end{tabular}

Source: Managed Data, 2019

The structural equations for this research model are:

Substructure 1:

$\mathrm{M}=\beta_{1} \mathrm{X}+\mathrm{e}_{1}$

$\mathrm{M}=0.255 \mathrm{X}+0.734$

Pei $=\sqrt{ } 1-0.457=0.734$

Substructure 2:

$\mathrm{Y}=\beta_{1} \mathrm{X}+\beta_{2} \mathrm{M}+\mathrm{e}_{2}$

$\mathrm{Y}=0.188 \mathrm{X}+0.219 \mathrm{M}+0.734$

Pei $=\sqrt{ } 1-0.457=0.734$

Checking model validity

There are two indicators to check model validity. namely the total determination coefficient and trimming theory as follows. The results of total determination coefficient:

$\mathrm{R}_{\mathrm{m}}{ }_{\mathrm{m}}=1$ - (1-0.457) (1-0.457)

$\mathrm{R}_{\mathrm{m}}^{2}=0.705$ 
It means that the diverse data that can be explained by the model was 70.5 percent or in other words, the information contained in the data of 70.5 percent could be explained by the model, while the remaining 29.5 percent was explained by other variables (not contained in the model) and error.

Trimming Theory

The validity test on each path for direct effect was the same as the regression, using the pvalue of the t-test, namely testing the variable regression coefficient partially standardized with expertise $(\mathrm{X})$ to work motivation $(\mathrm{M})$ was $3.972 \mathrm{sig} 0.000$, with expertise $(\mathrm{X})$ to employee performance (Y) was 2.420 with sig 0.017 , with work motivation variable (M) to employee performance (Y) was 2.125 with sig 0.036 .

Regression Analysis of Mediation Variable Using Sobell Test Method

The test of mediation variable mediating the relationship between dependent and independent variables consisted of the following stages: Indirect effect of expertise to employee performance through work motivation:

$$
\begin{aligned}
& a=0.255 \\
& s a=0.064 \\
& b=0.219 \\
& s b=0.103
\end{aligned}
$$

Counting the $\mathrm{S}_{\mathrm{ab}}$

$$
\begin{aligned}
& \mathrm{Sab}=\sqrt{b^{2} s a^{2}+a^{2} s b^{2}+s a^{2} s b^{2}} \\
& \mathrm{Sab}=\sqrt{(0,048 * 0,004)+(0,065 * 0,011)+(0,004 * 0,011)} \\
& \mathrm{Sab}=0.001
\end{aligned}
$$

Counting the $\mathrm{ab}$

$\mathrm{ab}=0.255 \times 0.219$

$\mathrm{ab}=0.036$

Counting Z

$\mathrm{Z}=\frac{a b}{S a b}$

$\mathrm{Z}=\frac{0,036}{0,001}$

$\mathrm{Z}=36.0$

Determining Z-table with significance level of 0.05 was 1.96. Comparing Z-count (36.0) to Ztable (1.96). The conclusion is work motivation could mediate the relationship between expertise and employee performance.

\section{Model Interpretation}

The Effect of Expertise on Employee Performance

Based on the calculation results, the research significance level showed that the expertise variable significantly influenced employee performance by $0.017<0.05$, so H1 was accepted. In other words, the first hypothesis that expertise had a positive and significant effect on the employee performance in PT Dinamika Abadi Medan could be accepted.

The Effect of Expertise on Work Motivation

Based on the calculation results, the research significance level of expertise variable to work motivation was $0.000<0.05$, so $\mathrm{H} 2$ was accepted. In other words, the second hypothesis that 
Syawaluddin, Erwin and Joni (2020), "The effect of expertise on employee performance with work motivation as intervening variable", Management and entrepreneurship: trends of development, Vol. 2, Issue 12, pp. 36-47, available at: https://doi.org/10.26661/2522-1566/2020-2/12-03

expertise had a positive and significant effect on work motivation in PT Dinamika Abadi Medan could be accepted.

The Effect of Work Motivation on Employee Performance

Based on the calculation results. the research significance level for the work motivation variable to employee performance was $0.036<0.05$, so $\mathrm{H} 3$ was accepted. In other words, the third hypothesis that work motivation had a positive and significant effect on the employee performance in PT Dinamika Abadi Medan could be accepted.

The Effect of Expertise on Employee Performance through Work Motivation Mediation

With the following criteria:

The calculation resulted in $\mathrm{Z}_{\text {count }}(36.0)>\mathrm{Z}_{\text {table }}$ (1.96). It means that work motivation could mediate the relationship between expertise and employee performance.

\section{RESULTS AND DISCUSSION}

\section{The Effect of Expertise on Employee Performance}

Based on the empirical test results, the research significance level for the expertise variable had a significant effect on employee performance by $0.017<0.05$. Therefore, H1 was accepted. In other words, expertise had a significant effect on employee performance in PT Dinamika Abadi Medan.

\section{The Effect of Expertise on Work Motivation}

Based on the empirical test results, the research significance level for the expertise variable to work motivation was $0.000<0.05$. Hence, H2 was accepted. In other words, expertise had a significant effect on work motivation in PT Dinamika Abadi Medan.

\section{The Effect of Work Motivation on Employee Performance}

Based on the empirical test results, the research significance level for the work motivation variable to employee performance was $0.036<0.05$, so $\mathrm{H} 0$ was rejected, and $\mathrm{H} 3$ was accepted. In other words, work motivation had a significant effect on employee performance in PT Dinamika Abadi Medan.

\section{The Effect of Expertise on Employee Performance through Work Motivation Mediation}

Based on the empirical test resulted in $\mathrm{Z}$ count (36.0) $>\mathrm{Z}$ table (1.96). It means that work motivation could mediate the correlation between expertise and employee performance.

\section{CONCLUSION}

The conclusions of this study are as follows:

Based on the empirical test results, the research significance level showed that the expertise variable significantly influenced employee performance with a correlation value of 0.188 and a significant value of $0.017<0.05$, so $\mathrm{H} 1$ was accepted. In other words, expertise had a significant effect on employee performance in PT Dinamika Abadi Medan. This case means that the higher the expertise provided, the higher the employee performance in PT Dinamika Abadi Medan. Based on the empirical test results, the research significance level was obtained for expertise variable to work motivation with a correlation value of 0.255 and a significant value of $0.000<0.05$, so H2 was accepted. In other words, expertise had a significant effect on work motivation in PT Dinamika Abadi Medan. This case means that the higher the expertise provided, the higher the work motivation of employees in PT Dinamika Abadi Medan. Based on the empirical test results, the research significance level was attained for work motivation variables to employee performance with a correlation value of 0.219 and a significant value of $0.036<0.05$, so H3 was accepted. In other words, work motivation had a significant effect on the employee performance in PT Dinamika 
Abadi Medan. This case means that the higher the employees' work motivation, the higher the employee performance in PT Dinamika Abadi Medan. The empirical test resulted in Z count (36.0) > Z table (1.96) so that work motivation could mediate the relationship between expertise and employee performance. Therefore, $\mathrm{H} 4$ was accepted. This case means that the higher the expertise provided, the higher the employee work motivation so that employee performance increased as well.

\section{REFERENCES}

Amelia, G.A.M. (2018), Pengaruh Keahlian Terhadap Kinerja Karyawan Dengan Kepuasan Kerja Sebagai Variabel Intervening Studi Pada PT. Clipan Finance Indonesia Tbk Bali, [Effect of Expertise on Employee Performance with Job Satisfaction as an Intervening Variable Study at PT Clipan Finance Indonesia Tbk Bali], Thesis, Indonesian Hindu University, (in Indonesian).

Andika, G. M. D. (2017), Pengaruh Display Terhadap Intensitas Membeli Dimediasi Oleh Kesadaran Merek Pada PT.Coca Cola Nusra WSP Di Denpasar, [Effect of Display on Purchasing Intensity Mediated by Brand Awareness at PT.Coca Cola Nusra WSP in Denpasar], Thesis, Indonesian Hindu University, (in Indonesian).

Damayanti, A. P., Susilaningsih and Sumaryati, S. (2013), "Pengaruh Keahlian dan Motivasi Kerja Terhadap Kinerja Karyawan Perusahaan Daerah Air Minum (PDAM) Surakarta", Jupe UNS, Vol 2, No $1, \quad$ pp. 155-168, available at: http://jurnal.fkip.uns.ac.id/index.php/ekonomi/article/view/2832 (Accessed 10 March 2020), (in Indonesian).

Dessler, G. (2003), Manajemen Sumber Daya Manusia, Penerbit PT Indeks: Jakarta, (in Indonesian).

Dhermawan, A.A.N.B., Sudibya, I.G.A., and Utama, I.W.M. (2012), "Pengaruh Motivasi, Lingkungan Kerja, Kompetensi Dan Keahlian Terhadap Kepuasan Kerja Dan Kinerja Pegawai Di Lingkungan Kantor Dinas Pekerjaan Umum Provinsi Bali", [The influence of motivation, work environment, competence and compensation on job satisfaction and performance of employees in the Office of Public Works Office of Bali Province], Journal of Management, Business Strategy and Entrepreneurship, Vol. 6, No. 2., (in Indonesian).

Efendi (2002), Manajemen Sumber Daya Manusia, [Human Resource Management], Grasindo, Jakarta, (in Indonesian).

Emron, E. et al. (2017), Manajemen Sumber Daya Manusia (Strategi dan Perubahan dalam Rangka Meningkatkan Kinerja Pegawai dan Organisasi), [Human Resource Management (Strategies and Changes in Order to Improve Employee and Organizational Performance)], Bandung: Alfabeta, (in Indonesian).

Firmandari, N. (2014), "Pengaruh Kompensasi Terhadap Kinerja Karyawan Dengan Motivasi Kerja Sebagai Variabel Moderasi (Studi Pada Bank Syariah Mandiri Kantor Cabang Yogyakarta)”, [Effect of Expertise on Employee Performance with Work Motivation as a Study Moderation Variable at Bank Syariah Mandiri Yogyakarta Branch Office], Jurnal Ekonomi dan Bisnis Islam, Vol. IX, No. 1, pp. 25-34, available at: http://ejournal.uinsuka.ac.id/syariah/Ekbisi/article/view/360 (in Indonesian).

Gibson et al. (1987), Organisasi: Perilaku, Struktur, Proses. [Organization: Behavior, Structure, Process], Fifth Edition, Volume 1, Interpreting Djarkasih, Erlangga Jakarta, (in Indonesian).

Hani, H. T. (2011), Manajemen Personalia dan Sumberdaya Manusia, [Personnel Management and Human Resources], Yogyakarta: Penerbit BPFE, (in Indonesian).

Harbani, P. (2007), Teori Administrasi Publik, [Public Administration Theory], Bandung: Alfabeta, (in Indonesian). 
Syawaluddin, Erwin and Joni (2020), "The effect of expertise on employee performance with work motivation as intervening variable”, Management and entrepreneurship: trends of development, Vol. 2, Issue 12, pp. 36-47, available at: https://doi.org/10.26661/2522-1566/2020-2/12-03

Herdian, D. A. (2010), Pengaruh Keahlian Terhadap Kinerja Karyawan PT. Slamet Langgeng Purbalingga Dengan Motivasi Kerja Sebagai Variabel Intervening, [Effect of Expertise on Employee Performance of PT. Slamet Lasting Purbalingga With Work Motivation As Intervening Variable], Thesis, Universitas Diponegoro, (Accessed 10 March 2020), available at: http://eprints.undip.ac.id/23253/1/Lengkap.pdf (in Indonesian).

Hidayat, A. N. (2016), Pengaruh kompensasi terhadap kinerja karyawan dengan motivasi sebagai variabel intervening (Pada Karyawan Direktorat Jendral Pajak Sleman), [Effect of compensation on employee performance with motivation as an intervening variable (On Employees of the Sleman Directorate General of Taxes)], Thesis, UPN "Veteran", Yogyakarta, available at: http://eprints.upnyk.ac.id/6606/ (Accessed 16 March 2020), (in Indonesian).

Kusumah, D.S.W., Sulaeman, U.E. and Hasbullah, R. (2018), "Pengaruh kepemimpinan, motivasi kerja dan kompensasi terhadap kinerja (studi pada pegawai kantor imigrasi kelas ii Karawang)", Jurnal Buana Ilmu, Vol.2, No. 2, pp. 33-49, (in Indonesian), available at: https://doi.org/10.36805/bi.v2i2.336 (Accessed 16 March 2020), (in Indonesian), DOI: 10.36805/bi.v2i2.336

Malay, H. (2002), Manajemen Sumber Daya Manusia, [Human Resource Management], Earth Literacy, Jakarta, (in Indonesian).

Malay, H. (2005), Manajemen Sumber Daya Manusia, [Human Resources Management: Revised Edition], Earth Literacy, Jakarta, (in Indonesian).

Malay, H. (2008), Manajemen Sumber Daya Manusia, [Human Resource Management], 2d Edition, Earth Literacy, Jakarta, (in Indonesian).

Mathis, R. L. and Jackson, J. H. (2002), Human Resource Management, Salemba Empat: Jakarta.

Mayangsari, B. E. (2018), Pengaruh Gaya Kepemimpinan, Keahlian Dan Semangat Kerja Terhadap Kinerja Karyawan PT.Depriwangga, [Influence of Leadership Style. Expertise and Work Spirit on Employee Performance of PT Depriwangga], Thesis, Mercu Buana University Jakarta, available at: https://repository.mercubuana.ac.id/40564/ (Accessed 18 March 2020), (in Indonesian).

Moeheriono (2012), Pengukuran Kinerja Berbasis Kompetensi, [Competency Based Performance Measurement], Jakarta: Raja Grafindo Persada, (in Indonesian).

Nugroho (2009), Public Policy, Elek Media Komputindo, Jakarta, (in Indonesian).

Nurcahyani, N. M. and Adnyani, I. G. A. D. "Pengaruh kompensasi dan motivasi terhadap kinerja karyawan dengan kepuasan kerja sebagai variabel intervening", [Effect of Expertise and Motivation on Employee Performance with Job Satisfaction as an Intervening Variable], EJurnal Manajemen, Vol. 5, No. 1, pp. 500-532, available at: https://ojs.unud.ac.id/index.php/Manajemen/article/view/16159, (Accessed 18 March 2020), (in Indonesian).

Omolo, P. A. (2015), "Effect of motivation on employee performance of commercial banks in Kenya: A case study of Kenya Commercial Bank in Migori County", International Journal of Human Resource Studies, Vol. 5(2), pp. 87-103, available at: http://dx.doi.org/10.5296/ijhrs.v5i2.7504 (Accessed 11 March 2020), DOI: 10.5296/ijhrs.v5i2.7504.

Payaman, S. (2001), Pengantar Ekonomi Sumber Daya Manusia, [Introduction to Human Resource Economics], Jakarta: LPFEUI, (in Indonesian).

Revita, H. (2017), Pengaruh Keahlian dan Motivasi Terhadap Kinerja Karyawan PT Indocitra Anugerah Semesta [The Effect of Expertise and Motivation on the Performance of PT Indocitra Anugerah Semesta's Employees], Thesis, Maranatha Christian University, available at: https://repository.maranatha.edu/22144/ (Accessed 12 March 2020), (in Indoneian).

Robbins, S. P. (2007), Perilaku Organisasi, [Organizational behaviour], Salemba Empat, Jakarta, (in Indonesian). 
Sugiyono (2013), Metode Penelitian Pendidikan (Pendekatan Kuantitatif, Kualitatif, dan R\&D), [Educational Research Methods (Quantitative Approach. Qualitative and R\&D)], Bandung: Alfabeta, (in Indonesian).

Sugiyono (2014), Metode Penelitian Manajemen, [Management Research Methods], Bandung: Alfabeta, (in Indonesian).

Soemarso (2009), Akuntansi Suatu Pengantar [Accounting. An Introduction], Book 2, Issue 5, Jakarta: Salemba Empat, (in Indonesian).

Simamora (2004), Panduan Riset Perilaku Konsumen, [Consumer Behavior Research Guide], Jakarta: PT Gramedia Pustaka Utama, (in Indonesian).

Tangkilisan, H. N. S. (2005), Manajemen Publik, [Public Management], Jakarta: Gramedia Widia Sarana Indonesia, (in Indonesian).

Yensy, B. Nurul Astuty (2010), "Pengaruh kompensasi dan motivasi terhadap kinerja guru di SMA Negeri 2 Argamakmur Bengkulu Utara" [The Effect of Expertise and Motivation on Teacher Performance (Study at SMA Negeri 2 Argamakmur, North Bengkulu)], Jurnal Kependidikan Triadik, Vol. 13, No. 1, pp. 33-42, available at: http://repository.unib.ac.id/262/ (Accessed 14 March 2020), (in Indonesian).

\section{ВПЛИВ ЕКСПЕРТИЗИ НА ЕФЕКТИВНІСТЬ ПРАЦІВНИКІВ З УРАХУВАННЯМ МОТИВАЦІЇ ЯК ПРОМІЖНОЇ ЗМІННОЇ}

\section{Syawaluddin}

STIE Professional Manajemen

College Indonesia

Медан, Індонезія
Erwin

STIE Mikroskil

Медан, Індонезія

\author{
Joni \\ STMIK TIME \\ Медан, Індонезія
}

Дане дослідження спрямоване на аналіз впливу експертизи на продуктивність співробітників в PT Dinamika Abadi Medan 3 урахуванням мотивації в якості проміжної змінної. В даному дослідженні взяли участь 124 співробітника компанії. Інструменти аналізу даних, що використовуються при перевірці гіпотез: валідність, надійність і аналіз шляху. Результати дослідження показали, що експертиза мала значний вплив на роботу співробітників в PT Dinamika Abadi Medan. Це означає, що чим вище рівень проведеної експертизи, тим вище ефективність роботи співробітника в PT Dinamika Abadi Medan. Експертиза істотно вплинула на трудову мотивацію співробітників в ПТ «Динаміка Абаді Медан». В ході дослідження було виявлено, що чим вище рівень проведеної експертизи, тим вище й трудова мотивація співробітників в PT Dinamika Abadi Medan. Трудова мотивація мала значний вплив на ефективність роботи співробітників в PT Dinamika Abadi Medan. Відповідно, чим вище мотивація працівника, тим вище його продуктивність в РT Dinamika Abadi Medan. Емпіричний тест показав, що трудова мотивація може опосередковувати взаємозв'язок між досвідом і ефективністю співробітників і привів до висновку, що чим вище рівень проведеної експертизи, тим вище мотивація працівника, тому продуктивність праці співробітника також збільшується.

Ключові слова: експертиза, мотивація праці, результативність співробітників, бізнес компанії, людські ресурси. 
Syawaluddin, Erwin and Joni (2020), "The effect of expertise on employee performance with work motivation as intervening variable", Management and entrepreneurship: trends of development, Vol. 2, Issue 12, pp. 36-47, available at: https://doi.org/10.26661/2522-1566/2020-2/12-03

\section{ВЛИЯНИЕ ЭКСПЕРТИЗЫ НА ПРОИЗВОДИТЕЛЬНОСТЬ РАБОТНИКОВ С УЧЁТОМ МОТИВАЦИИ КАК ПРОМЕЖУТОЧНОЙ ПЕРЕМЕННОЙ}

\section{Syawaluddin}

STIE Professional Manajemen

College Indonesia

Медан, Индонезия

\author{
Erwin \\ STIE Mikroskil \\ Медан, Индонезия
}

\author{
Joni \\ STMIK TIME \\ Медан, Индонезия
}

Данное исследование направлено на анализ влияния экспертизы на производительность сотрудников в PT Dinamika Abadi Medan с учётом мотивации в качестве промежуточной переменной. В данном исследовании приняли участие 124 сотрудника компании. Инструменты анализа данных, используемые при проверке гипотез: валидность, надежность и анализ пути. Результаты исследования показали, что экспертиза оказала значительное влияние на работу сотрудников в PT Dinamika Abadi Medan. Это означает, что чем выше уровень проводимой экспертизы, тем выше эффективность работы сотрудника в PT Dinamika Abadi Medan. Экспертиза существенно повлияла на трудовую мотивацию сотрудников в ПТ «Динамика Абади Медан». В ходе исследования было выявлено, что чем выше уровень проводимой экспертизы, тем выше трудовая мотивация сотрудников в PT Dinamika Abadi Medan. Трудовая мотивация оказала значительное влияние на эффективность работы сотрудников в PT Dinamika Abadi Medan. Соответственно, чем выше мотивация работника, тем выше его производительность в РT Dinamika Abadi Medan. Эмпирический тест показал, что трудовая мотивация может опосредовать взаимосвязь между опытом и эффективностью сотрудников и привел к выводу, что чем выше уровень проводимой экспертизы, тем выше мотивация работника, поэтому производительность труда сотрудника также увеличивается.

Ключевые слова: экспертиза, мотивация труда, результативность сотрудников, бизнес компании, человеческие ресурсы. 